\title{
Activity Based Teaching and Learning through Mentoring in Punjab Province of Pakistan: An Analysis
}

\author{
Dr. Muhammad Akhalq \\ Dy. District Education Officer, Department of Education, Punjab, Pakistan \\ mmakhlaq2009@gmail.com
}

\section{Dr. Saeed ul Hassan Chishti}

Project Director, IPD, International Islamic University, Islamabad

\section{Dr. Muhammad Zafar Iqbal}

Assistant Professor, Department of Education, International Islamic University, Islamabad Zafar.phdedu57@iiu.edu.pk

\author{
Doi:10.5901/mjss.2016.v7n1s1p434
}

\section{Abstract}

This paper studies the effects of mentoring process on the professional development of teachers through Activity Based Teaching and learning. Major objectives of the study includes: i) To review the mentoring process initiated for the Professional Development of Primary School Teachers in Punjab Province of Pakistan, and ii) To analyze the effects of mentoring process to promote Activity Based Learning among the Elementary Level Teachers in Punjab Pakistan. The population of the study was comprised on 47988 Primary School Teachers (Mentees) and 1370 District Teachers Educators (Mentors). The data was collected through questionnaires and interviews from the 381 Primary School Teachers (PSTS) and 302 District Teachers Educators (DTES) were taken from the selected 12 districts of the Punjab. The difference in the scores of PSTS and DTES showed that PSTS \&DTEs mean opinion scores were noted respectively. Major recommendations of this study were; i) The training duration of the District Teacher Educators may be enhanced to enable them to prepare the Primary School Teachers for developing supporting materials that matches with the mental abilities of their students, when they are involved in Activity Based Learning, Keeping in the view societal, cultural, religious barriers and gender sensitization of the Pakistani context, female District Teacher Educators be recruited to provide mentoring services to the female Primary School Teachers to make the Activity Based Learning more effective.

Keywords: Mentoring, Professional Development, Benefits, Activity Based Teaching and Learning

\section{Introduction}

The term mentoring has its roots in the ancient Greek. Generally, a mentor perceived as a trusted, older, experienced and wise person who intensely guides a younger individual in many aspects of his/ her life (Yoder, 2001 \& Carden, 2010). Mentoring is a recent term but during the history of mankind the word "Mentor" was initially used by Socrates and Plato, Hayden and Beethoven. During 1980s, many states started and district mentoring programmes focusing on teacher's preparation and their professional development. In U.K. and other European countries mentoring was started in 1960 for the purpose of professional development of novice teachers to achieve the already set professional targets Clutterbuck, (1991a). Freud and Jung (1910) quoted Butcher (1890) that the roots of mentoring are linked with the "mythology story" of Ancient Greece. The origin of mentoring was evolved when the renowned king "Ulysses" send his son "Telemachus" to an old friend for the education and training (Fitzgerald, 1961). The word "mentor' refers to a trusted friend, advisor, teacher, wise person or an experienced person. In this mentoring relationship entrusted friend "mentor" became a counselor, sponsor, guide, coach, teacher, confident advisor and protector to Telemachus i.e. "Mentee" (Yoder, 2001). The renowned poem which is frequently quoted in literature on mentoring titled "The Odyssey" by Homers demonstrated the concept of mentoring was at least 3,000 years old. Homer was the scholar man in the entire history of mankind who floated the idea of mentoring (CNA, 1994). The term mentoring was firstly used in the United States during $19^{\text {th }}$ century (Clutterbuck, 2001 \& 2004) as cited by Stodgill (2010) who had sought the mentor as an ambiguous authority figure. Clutterbuck (1991a) stated that in Africa different countries used different practices of mentoring for training of employees 
and to improve the health services. During 1980s several organizations used mentoring programmes to train their junior members and middle managers in Japan. Similarly, in the subcontinent the term of Guru and Chilla refers to the concept of mentoring as quoted by the different religious scholars (Feeney, 2007).

Mentoring process is configured as an aberration ranging from informal buddy systems to formal and highly structured mentorship. Through the mentoring process teachers receives technical assistance, career advancement and psychological support from an experienced teacher. This assistance and support is transmitted through observation, discussions, questioning and planning. Mentoring is two way process and provide a career path growth and enrichment for the advancement of knowledge to each individual of their respective deficient areas (Bey and Holmes, 1992; Fanure, 2000).

In this modern era, mentoring process has been emerged as a professional development technique in the fields of medicine, engineering, agricultural management and education to improve the professional skills of teachers throughout their careers development (Johnson, 2007). The mentoring of teachers is characterized as approachability on the part of an experienced educator and receptivity by the neophytes. According to Little (2010 \& Harris 2006) stated that a mentoring programme should have following elements; (i) effective training in communication and peer coaching techniques (ii) Focus must be given to the professional problems of the teachers (iii) Special consideration be given at the beginning of the academic year, and (iv) Regular meetings between mentors and mentees be planned throughout the year. American National Commission on Future Teaching formulated 1996 has that the ideally mentoring programme should be well organized and well supported. It must be planned with low levels of teacher effectiveness and high rates of erosion. Results of different studies revealed that teachers are more likely to continue teaching in the schools in which they originally receive mentoring in their subject areas. According to Jhonson et. al. (2004) mentors and mentees should have mutual interactions so that meaningful conversation should occur about teaching.

The importance of the mentoring is recognized by various scholars in education areas. (Levinson et.al. 1978) conducted a longitudinal study and established that mentoring relationships are important for professional development of novice teachers. The important function of mentoring is to support and facilitate the mentee to fulfill his/her emerging professional needs (Levinson et.al., 1978). For the purpose of this study, mentoring is defined as educational reforms designed by the Directorate of Staff Development to provide support and training to in-service teachers as part of their professional development. Smith and Ensher (2004) say that in an effective mentoring programme the mentors and mentees should be paired from the same subject and grade level. The mentors and mentees classrooms should be in close vicinity to each other. Mentor provides valuable support to mentee to answer the questions by, sharing lesson plans, class observations and provide a valuable encouragement. Tourigny (2005) found that consultants who professionally train mentors stated that it was better for a school to have no mentoring programme at all than to have a bad mentoring programme.

\section{Pre-Requisites for Mentoring}

Traditionally, mentoring process required as a dyadic, face-to-face, long-term relationship between a supervisory adult and beginner teacher that fosters the mentee's academic, or personal and professional development (Donaldson, Ensher, \& Grant-Vallone, 2000). During this process, experienced educator acts as a role model, for novice teachers. It is a sympathetic learning relationship between a caring individual who shares knowledge, experience, wisdom with another individual who is ready and willing to develop his/her professional skills. The most suitable way to improve capacity is teachers training and it is a continuous process which enables teachers to perform their duties efficiently. The influence of the experienced person is pervasive and enduring, while still honoring the autonomy of the neophyte teacher.

Mentoring always related to the professional needs of (Allen\& Day 2002). A supportive learning relationship between a caring teacher who shares experiences with other teachers who are ready and willing to develop their professional skills. Typically, mentoring is a term used to describe a relationship between a less experienced individual called a "mentee" and a more experienced individual known as a "mentor". The process of mentoring is considered as an interaction between a more experienced teacher and less experienced teacher of same field or area. Mentor helps guides and encourages to the less experienced person through counseling and coaching fulfilling their professional needs (Johnson, 2007). Generally mentoring process includes following objectives; i) to enhance the skills, knowledge and professional development of mentees, ii) to facilitate the mentees towards professional innovation, iii) to help and guide the mentees to acquire professional knowledge, customs and values, and iv) to provide a role model for the mentee's professional development (Levinson, 1978). 


\subsection{Activity Based Teaching and Learning}

There is a famous saying of Confucius about the successful learning is "Tell me, and I will forget, Show me, and I may remember, Involve me, and I will understand". The involvement in learning always takes place through Activity Based Teaching where teachers work as facilitator, motivator, guide and a coach not a sage on the stage (Stolen 2009)). Boud \& Feletti (1999) discussed that Activity Based Teaching and Learning encourage students to learn how to learn" through different activities which are related to the real life problems. Teo \& Wong (2000) view that traditional teaching approaches do not encourage students to associate with previously acquired knowledge but Activity Based Teaching remedially focused on these circumstances. Activity Based Learning and Learning is an approach in which students actively participate in learning based their experiences rather than sit as passive listeners. Learning activities are based on real life practices which help the students to transform understanding in personal knowledge which is further applied in different situations (Edward, 2001; Harfield, Davies, Hede, Panko Kenley, 2007)). Marilyn and Higgins (1977) define Activity Based Learning and Learning a process in which student is actively involved in doing or in seeing something done and it frequently involves the use of manipulative materials. In Activity Based Teaching and Learning students talk about what they are learning, write about and relate it to practical situation. In this way students motivation level remained higher because of their personally envolvement in learning (Chickering \& Gamson 1987; Harel and Papert 1991, Kafai and Resnick 1996, Hug, Krajcik, and Marx 2005).

Often teachers' uncertainty, lack of resources, material management, problems, discomfort, lack of time, educational backgrounds dependency on textbooks affects their involvement in activities (Lebuffe, 1994; Morey, 1990; Tilgner, 1990). The important feature of the Activity Based Teaching and Learning is learning by doing. It also allows learners to study according to their own ability and skills that, i) What they learned, ii) How they learned it, iii) What they do not understand, iv) Why they do not understand it , and v) What assistance they would like to receive.

According to Churchill (2003) Activity Based Learning and Learning helps students to construct mental models which are pre-requisite for problem solving and transformation of skills. Hake (1998) argues that Activity Based Teaching and Learning is a motivational process in which students are motivated by engaging them in effective interactive activities. Activity Based Learning and Learning based on constructive approach (Hein, 1991, Stoblein 2009). According to constructivist view of learning each person constructs his/ her own knowledge and learning process based on previous experiences. For construction students, it is imperative to have variety of activities in active classrooms settings (Abdelhamid, 2003, Murray, Donohoe and Goodhew, 2004). ABL promotes team working, communication, problem solving, reflection and life-long learning skills among learners. Involvement in activities helps students to apply their knowledge in practical life and prepare the future goals of life.

According to Brophy (1995) Activity Based Teaching and Learning approach is imperative to clarify students concepts in different context e.g. classroom lecture, laboratory experiments and textbook reading activities. Active engagement in learning activities develops conceptual understanding and motivates students to seek further information found that Activity Based Teaching and Learning significantly improves conceptual understanding of the students in their respective subject (Brophy, 1995; Hake (1998).

\subsection{Activity Based Teaching and Learning Through Mentoring}

Activity Based Learning requires a wide range of pedagogical approaches. Its foundation premises consist of the requirement that learning should be based on doing reading hand outs experiments and activities. The activity-based learning is rooted in the common notion that children are active learners rather than passive recipients of information. If the students are provided the opportunity to explore by their own then the optimum learning environment and learning will becomes joyful and long-lasting. The key feature of the Activity Based Learning is that it uses child-friendly educational aids to foster self-learning and allows every student to study according to ones aptitude and skills. In Activity Based Learning system, the curriculum is divided into small units, each a group strike attractively to design study cards. When a child finishes a group of cards, he completes one "milestone". Activities in each milestone may include games, rhymes, drawing, and songs to teach a letter or a word, form a sentence, or understand a concept. The student takes up an Exam Card only after completing all the milestones in a subject.

\subsection{Mentoring in Punjab Province of Pakistan}

In Pakistan, mentoring process was initiated by the Punjab province during 2007 for the professional development of primary school teachers under the umbrella of Continuous Professional Development programmes. 


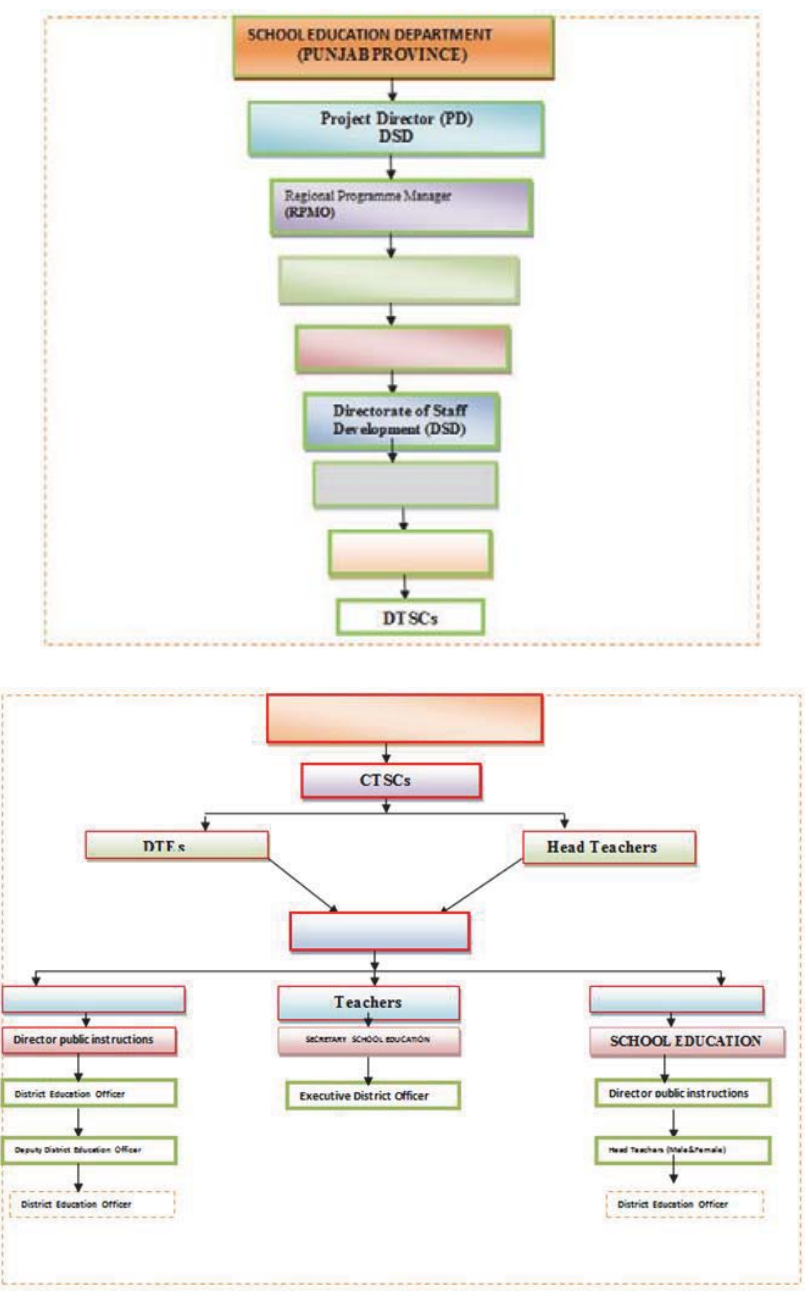

As visualized by the Government of Punjab (2010) the most important objective of mentoring program was to identify the professional development needs of Primary School Teachers and to accelerate students leaning at primary level in the province. It should focus on changing the classroom practices, especially on changing how teachers teach and how children learn (Glasser, 2009). Changing these practices requires a long term relationship with the individual teacher, understanding of the learner and classroom context, joint planning and collective work with the teacher, and continuous support to the teacher (Gless, 2006). The teacher mentoring and support cannot be separated from students learning.

Since the creation of Pakistan all education policies were determined in their objectives and critical of past failures (Govt. of Pakistan 2008). A common feature of all policies, plans, programmes and schemes recommended the professional development for all categories of teachers but pace of implementation remained at variance. Over the years, the basic features of various education policies have remained the same, with every new policy adding to the objectives of the previous ones.

\subsection{Mentoring Areas}

In Punjab the CPD was started during 2003 with the objective to maintain, improve and broaden the professional skills and knowledge of the Primary School Teachers. It also focuses on the development of personal qualities, necessary for the execution of professional and technical duties throughout professional life. In this CPD framework School Education 
Department of the province was fully involved. The School Education Department has two wings i.e. administration wing and training wing (DSD). The Secretary School Education is the provincial head of the School Education Department. "Taleemi Calendar, Activities Based Teaching and Learning, Used of Support Material, Interaction with Students, Classroom Management, Students Assessment and Home Work.

The present study focused Mentoring Area-3 "Activity Based Teaching and Learning". The primary objective of mentoring is to fulfill the professional development needs and organize training courses for PSTs within the CPD framework. The District Teacher Educator trained the PSTs in such a way that he may be able to perform his duties effectively and efficiently. Professional development of PSTs under the District Teacher Educator system is being executed in the eight mentoring areas. These eight mentoring areas are comprehensive for the professional development of PSTs. Development plan guidance in the mentoring area-3 "Activity Based Teaching and Learning" The detail of mentoring area-3 "Activity Based Teaching and Learning" is discussed as under.

\begin{tabular}{|c|c|}
\hline Level of PSTs & Action plan for the PSTs \\
\hline Basic level (level 0 to1) & $\begin{array}{l}\text { Teacher will think about an activity for the students and will reflect it in his/her diary and the } \\
\text { lesson plan. } \\
\text { The teacher will ensure that he/she has all the teaching resources to perform this activity in the } \\
\text { classroom. }\end{array}$ \\
\hline Intermediate level (level1to2) & $\begin{array}{l}\text { The teacher will plan an activity and will reflect it in his/her lesson plan and he will also endorse it } \\
\text { in the classroom teacher diary. } \\
\text { The teacher will ensure that he/she has all kinds of resources to conduct the activity in the } \\
\text { classroom. }\end{array}$ \\
\hline Advanced level (level 2to3) & $\begin{array}{l}\text { The teacher will plan a variety of activities from the teacher guide and reflect it in the lesson plan } \\
\text { and write it in teacher diary. } \\
\text { The teacher will select various activities to employ the maximum number of students in the } \\
\text { available teaching resources and time. }\end{array}$ \\
\hline
\end{tabular}

DTE Coaching Guide (2013)

Major objectives of this study includes:-

\section{Objectives}

1. To review the mentoring process initiated by the Directorate of the Staff Development for the Professional Development of Primary School Teachers in Punjab Province of Pakistan.

2. To analyze the effects of mentoring process to promote Activity Based Learning among the Elementary Level Teachers in Punjab Pakistan.

\section{Research Questions}

1. To what extent Activity Based Teaching and Learning is effective in mentoring process of the Primary School Teachers in Punjab Province?

2. To what extent mentoring process helps to Primary School Teachers in developing positive attitude towards $\mathrm{ABL}$.

3. To what extent process of mentoring launched in Punjab Province facilitated the Primary School Teachers in assessing the student's learning.

4. To what extent mentoring process helps to Primary School Teachers in organizing the curriculum related activities within the framework of $A B L$.

\section{Hypotheses}

$\mathrm{H}_{01}$ The mean opinion scores of the PSTs and the DTEs significantly differ that mentoring process helps them out to apply the $A B L$ in practical classroom settings.

\section{Methodology}

The research design of this study was mixed method and it was delimited to twelve districts of Punjab province; 1) Attock, 
2) Sargodha, 3) Gujarat, 4) Mandi Bahuddain. Din, 5) Okara, 6) Mainwali, 7) Muzffaarghar, 8) Shakhpura,9) Faisalabad, 10) Raheem Yar Khan, 11) Rajanpur, and 12) Kasur districts. The study was delimited to only Mentoring Area-3 "Activity Based Teaching and Learning".

\section{Population and Sample}

The population of the study comprised of 47988 Primary School Teachers and1370 District Teachers Educators. Simple random sampling technique was used to select the sample from selected districts. The sample consisted of 302 District Teachers Educators and 381 Primary School Teachers from the 12 districts of Punjab Province. The data was collected personally through questionnaires and interviews from PSTs \& DTEs. The questionnaires of District Teachers Educators and Primary School Teachers were developed on five points Likert's scale. The data collection was finished over six months containing two major phases i.e. quantitative data collection and qualitative data collection. Keeping in view of the availability of the respondents, researcher approached them during May 2013 before the summer vacations.

The interviews were conducted personally by taking prior permission from the authorities. Content validity of the questionnaires was checked by discussions with experts of same area. Cronbach alpha was also verified by calculating the reliability of the both questionnaires through SPSS version 17. The calculated value of alpha was 0.87 which was satisfactory. The collected data was analyzed in using statistical treatment by calculating Percentages, Mean Scores and t-test was used to see that if there was significant difference between the means of the both groups Primary School Teachers (PSTs) and District Teacher Educators (DTEs). The data collected through interviews PSTs and DTEs was analyzed by using NVIVO version 10. The qualitative data provided comprehensive descriptions on the mentoring phenomenon and provided complete image of effects which are contributing towards the professional development of Primary School Teachers. The interviews were conducted in informal way with the $10 \%$ the Primary School Teachers (PSTs) 38 and 30 (10\%) the District Teacher Educators (DTEs).

\section{Results}

The total sample of Primary School Teachers 381, in which 163 (42.8 \%) were male and 218 (57.2\%) were female. The total sample of District Teacher Educators was 302, male 230 (76.2 \%) and female $72(23.8 \%)$. The detailed analysis along with all results on the mentoring area-3 "Activity Based Teaching and Learning" are given below in Table No-2

Table 1: Mean Opinion Scores of PSTS \&DTEs on the mentoring area-3 "Activity Based Teaching and Learning"

\begin{tabular}{|c|c|c|c|c|c|c|}
\hline Sr. No & Statement & Respondents & $\mathrm{X}$ & SD & $\begin{array}{c}\mathrm{t}- \\
\text { value }\end{array}$ & $\begin{array}{c}\mathrm{p}- \\
\text { value }\end{array}$ \\
\hline i. & Through mentoring process, my teaching has become more effective. & $\begin{array}{l}\text { PSTs }(\mathrm{N}=381) \\
\text { DTEs }(\mathrm{N}=302)\end{array}$ & $\begin{array}{l}3.09 \\
2.90\end{array}$ & $\begin{array}{l}1.579 \\
1.539\end{array}$ & 1.633 & 0.103 \\
\hline ii. & $\begin{array}{l}\text { Mentoring process helps the mentees in planning Activity Based Learning } \\
\text { teaching activities. }\end{array}$ & $\begin{array}{l}\text { PSTs }(\mathrm{N}=381) \\
\text { DTEs }(\mathrm{N}=302)\end{array}$ & $\begin{array}{l}2.84 \\
3.09\end{array}$ & $\begin{array}{l}1.586 \\
1.527\end{array}$ & 2.125 & 0.034 \\
\hline iii. & $\begin{array}{l}\text { Mentoring process helps in developing positive attitude towards Activity Based } \\
\text { Learning teaching. }\end{array}$ & $\begin{array}{l}\text { PSTs }(\mathrm{N}=381) \\
\text { DTEs }(\mathrm{N}=302)\end{array}$ & $\begin{array}{l}3.01 \\
2.99\end{array}$ & $\begin{array}{l}1.548 \\
1.539\end{array}$ & 0.988 & 0.324 \\
\hline iv. & $\begin{array}{l}\text { Mentoring process provide helps the mentees in assessing the student's } \\
\text { learning when they are involved in Activity Based Learning. }\end{array}$ & $\begin{array}{l}\text { PSTs }(\mathrm{N}=381) \\
\text { DTEs }(\mathrm{N}=302)\end{array}$ & $\begin{array}{l}3.11 \\
3.66 \\
\end{array}$ & $\begin{array}{l}1.620 \\
1.344 \\
\end{array}$ & 5.273 & 0.000 \\
\hline v. & $\begin{array}{l}\text { Mentoring process has deepened the understanding about Activity Based } \\
\text { Learning. }\end{array}$ & $\begin{array}{l}\text { PSTs }(\mathrm{N}=381) \\
\text { DTEs }(\mathrm{N}=302)\end{array}$ & $\begin{array}{l}3.30 \\
3.16 \\
\end{array}$ & $\begin{array}{l}1.515 \\
1.580\end{array}$ & 1.207 & 0.228 \\
\hline vi. & Mentoring process helps in organizing the curriculum related activities. & $\begin{array}{l}\text { PSTs }(\mathrm{N}=381) \\
\text { DTEs }(\mathrm{N}=302)\end{array}$ & $\begin{array}{l}3.13 \\
3.23 \\
\end{array}$ & $\begin{array}{l}1.544 \\
1.510 \\
\end{array}$ & 0.681 & 0.080 \\
\hline vii. & $\begin{array}{l}\text { Mentoring process helps the mentees in selecting various type of learning } \\
\text { activities. }\end{array}$ & $\begin{array}{l}\text { PSTs }(\mathrm{N}=381) \\
\text { DTEs }(\mathrm{N}=302)\end{array}$ & $\begin{array}{l}3.09 \\
3.07\end{array}$ & $\begin{array}{l}1.615 \\
1.548\end{array}$ & 1.832 & 0.067 \\
\hline viii & Mentoring process helps to perform all type of teaching activities in classroom. & $\begin{array}{l}\text { PSTs }(\mathrm{N}=381) \\
\text { DTEs }(\mathrm{N}=302)\end{array}$ & $\begin{array}{l}4.56 \\
4.11 \\
\end{array}$ & $\begin{array}{l}0.987 \\
1.172\end{array}$ & 3.192 & 0.001 \\
\hline ix & $\begin{array}{l}\text { Mentoring process helps the mentees in devising the lesson plans according to } \\
\text { the activities. }\end{array}$ & $\begin{array}{l}\text { PSTs }(\mathrm{N}=381) \\
\text { DTES }(\mathrm{N}=302)\end{array}$ & $\begin{array}{l}2.57 \\
3.26\end{array}$ & $\begin{array}{l}1.528 \\
1.662\end{array}$ & 10.726 & 0.000 \\
\hline
\end{tabular}

a) Table 1 (i) shows difference in the mean opinion scores of the PSTs and the DTEs on effective teaching through mentoring. The PSTs mean opinion score was 3.09 and the respondents DTEs mean opinion score was 2.90. The $t$-value was 1.633 , $(t=1.633, p>0.05)$ which was not significant at $p=0.05$ level of significance. Therefore, the Null Hypothesis $\mathrm{H}_{01}$ was not rejected. This revealed that the opinion of the PSTs and DTEs was 
more favorable with the statement that mentoring process helped the mentees in making their teaching more effective.

b) Table 1 (ii) indicates PSTs mean opinion score was 2.84 and DTEs mean opinion score was 3.09 . The t-value was 2.125 , i.e. $(t=2.125, p<0.05)$ which was significant at $p=0.05$ level of significance and the Null Hypothesis Ho1 was rejected. This depicted that the both groups of the respondents significantly differed on statement that mentoring process helped the mentees in planning Activity Based Learning teaching activities.

c) Table 1 (iii) depicts the difference between the mean opinion scores of PSTs \& DTEs about the development of positive attitude towards Activity Based Learning teaching. The mean opinion score of PSTs was 3.01 \& DTEs was 2.99. The calculated $t$-value was $0.988(t=0.988, p>0.05)$ which is not significant at $p=0.05$ level of significance. So, the Null Hypothesis $\mathrm{H}_{01}$ was not rejected. This showed that the respondents PSTs and DTES were in favorable opinions with the statement about the mentoring process helped the mentees in developing positive attitude towards Activity Based Learning teaching.

d) Table 1 (iv) reveals the difference between mean opinion score of PSTs was 3.11 and the mean score of DTEs was 3.66. The $t$-value was $5.273(t=5.273, p<0.001)$ which was overwhelmingly significant at $p=0.001$ level of significance. Therefore, the Null Hypothesis $\mathrm{H}_{01}$ was rejected. This showed that the respondents PSTs \& DTEs differed significantly in their opinions that mentoring process helped the mentees in assessing the students learning when they are involved in Activity Based Learning.

e) Table 1 (v) shows the mean opinion difference of PSTs \& DTEs on deepening the teaching and learning through mentoring. The PSTs mean opinion score was 3.30 and DTEs was 3.16. The $t$-value $(t=1.207, p>0.05)$ which was not significant at $p=0.05$ level of significance. Therefore, the Null Hypothesis Ho1 was not rejected. This showed there was no difference in the opinions of PSTs and DTEs towards the statement that mentoring process in deepening the understanding about teaching and learning.

f) Table 1 (vi) reflects the difference between the mean opinions scores of PSTs and DTEs in organizing the curriculum related activities. The calculated data showed that respondents PSTs mean opinion score was 2.57 and DTEs was 3.27. The t-value 0.680 was not significant at $p=0.05$ level of significance and the Null Hypothesis $\mathrm{H}_{01}$ was not rejected. This revealed that both PSTs and DTEs were in favorable opinions towards the statement that mentoring process helped the mentees in organizing the curriculum related activities.

g) Table 1 (vii) indicates that mentoring process helps the mentees in selecting various type of learning activities. Table reflects the difference between the mean opinions scores of PSTs and DTEs in organizing the curriculum related activities. The calculated data showed that respondents PSTs mean opinion score was 3.12 and DTEs was 3.22. The t-value 0.680 was not significant at $p=0.05$ level of significance and the Null Hypothesis $\mathrm{H}_{01}$ was not rejected. This revealed that both PSTs and DTEs were in favorable opinions towards the statement that mentoring process helped the mentees in organizing the curriculum related activities.

h) Table 1 (viii) reflects the difference between the mean opinions scores of PSTs and DTEs in perform all type of teaching activities in classroom. The calculated data showed that respondents PSTs mean opinion score was 4.56 and DTEs was 4.11. The t-value 3.192 was highly significant at $p=0.001$ level of significance and the Null Hypothesis Ho1 was not rejected. This revealed that both PSTs and DTEs were in favorable opinions towards the statement that mentoring process helped the mentees in performing all type of teaching activities in classroom.

i) Table 1 (ix) reflects the difference between the mean opinions scores of PSTs and in devising the lesson plans according to the activities. The calculated data showed that respondents PSTs mean opinion score was 3.12 and DTEs was 3.22. The t-value 10.726 was overwhelming significant at $p=0.001$ level of significance and the Null Hypothesis $\mathrm{H}_{01}$ was not rejected. This revealed that both PSTs and DTEs were in favorable opinions towards the statement that mentoring process helped the mentees in devising the lesson plans according to the activities.

\section{Analysis of the Interviews}

As this study formed on mixed methods paradigm, therefore two major procedures i.e. QUAL \& QUAN were employed. Mixed method mixed method research is an intentional use of more than one method or methodologies in the same research. The researcher held individual interviews with the following participants: 


\subsection{Analysis of the Interviews Primary School Teacher (PSTs)}

The total number of the PSTs respondents were 38 whose the interview was conducted. The details of analysis are given in the below mentioned graphs:-

Graph 1: Gender Wise Distribution of the Opinions of PSTs

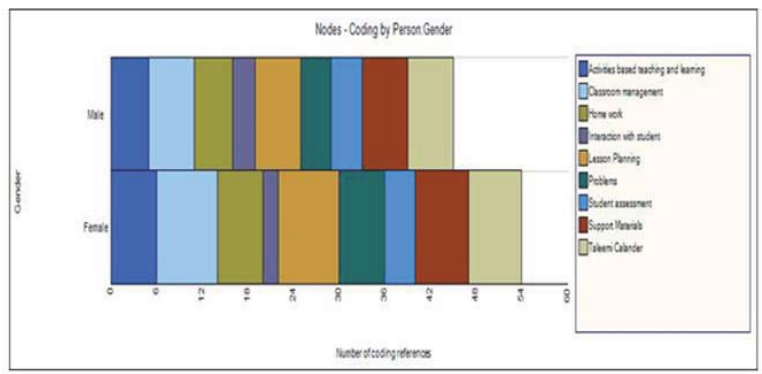

The graph 339 reflects the contents analysis of gender wise difference on the eight mentoring areas. The female respondents laid stress on the following areas: (i) Taleemi Calendar (ii) Lesson Planning, (iii) Activities Based Teaching and Learning, and (iv) Classroom Management While, the male respondent stressed on (i) Classroom Management, (ii) Lesson Planning, and (ii) Home Work. It is depicted from the analysis that female respondent stressed more on mentoring areas as compared to the male respondents. It is evident from the analysis that both the groups equally focused on the (i) Taleemi Calendar, (ii) Lesson Planning and (viii) Homework. Cooper (2006) stated that Activity Based Teaching and Learning is considered as outside classroom learning and it has long term benefits on students' achievement. Similarly one of the PST respondents said that "Activity Based Teaching contributes towards the effective learning and it helps in improving the grading of the students".

Graph 2: Gender Wise Distribution in the Opinions of DTES

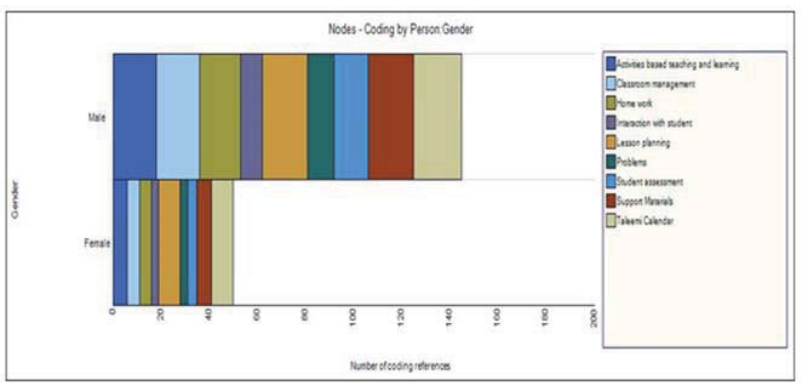

The above shows gender wise difference in the opinions in the data analysis on the eight mentoring areas. The male respondents having focused on the mentoring areas: (i) Taleemi Calendar, (ii) Lesson Planning, (iii) Classroom Management, (vi) Home Work and the respondents focused on the mentoring areas, (i) Taleemi Calendar, (ii) Lesson Planning, (iii) Support Material, and (iv) Home Work. Both of the respondents groups focused on the mentoring areas, (i) Taleemi Calendar, (ii) Lesson Planning, and (iii) Homework. Activity Based Teaching is a process that adopts mental ability of students' social norms and available resources in the teaching-learning environment. Activity Based Learning approach is a less of burden to learning and increasing the eagerness and happiness of student and school life. The Activity Based Teaching is a Child centered approach, where cognitive development is very important. Activity Based Teaching contributes joyful learning that is important in achieving the Student Learning Outcomes. Keeping this mind activity based learning is are well selected, planned and organized in education. It influences the student learning capacity. Activity based approach in education was emphasized by many. One of the DTE respondents said that in activity-based teaching teachers used different methods to draw the students' intentions into the lesson and made them as a partner of their own education. The teachers maintained environment to facilitate, engaging and making sure that students have become active in the learning process. It is accomplished through the creation of different activities and 
projects that students work that what they had learned. Activity Based Teaching requires a great deal of effort on the part of the Primary School Teachers. Activity Based Teaching using this mentoring method to create lessons plans that provide students with opportunities to take part in their education.

\section{Conclusions}

1. Primary School Teachers and District Teacher Educators opined that mentoring process helped the mentees in organizing the curriculum related activities to create attractiveness in the lesson. The respondents School Teachers and District Teacher Educators reported that mentoring process helped the mentees in making their teaching more effective.

2. Primary School Teachers and District Teacher Educators acknowledged that mentoring process helped the mentees in eliminating the feelings of professional isolation and developing positive attitude towards teaching

3. Mentoring process did not help the mentees to manage the teaching activities in a realistic way, to prepare such type of support material that matches with mental abilities of the students, to write down the clear learning objectives, to promote the desired behavior among the students, to identify the potential behavior problem of students and to provide the instruction which ensured that the assigned homework suited to the capabilities of students.

4. Through the findings of open ended questions it was found that there was dire need of provision of a science teacher and as well as support material kit in every school.

\section{Recommendations}

1. The training duration of the District Teacher Educators may be enhanced to enable them to prepare the Primary School Teachers for developing supporting materials that matches with the mental abilities of their students, when they are involved in Activity Based Learning.

2. Primary School Teachers reported in this study that it was difficult for them to manage activities for their multigrade students. Therefore, subject based mentoring may be introduced and separate mentors be appointed to provide mentoring facilities to those teachers who are teaching different subjects at primary school level to enable them to adopt Activity Based Learning in multi-grade teaching.

3. Keeping in the view societal, cultural, religious barriers and gender sensitization of the Pakistani context, female District Teacher Educators be recruited to provide mentoring services to the female Primary School Teachers to make the Activity Based Learning more effective.

\section{References}

Allen, G. \& Poteet, M. (2009). Are facilitated mentoring programme beneficial; A randomized experimental field study. Journal of Vocational Behavior, Vol. 72, No. 2, pp.351-357.

Anderson, E.M.,\& Shannon, A.L.(1995).Towards a conceptualization of mentoring. In T. Kerry, \& A.S. Mayes (Eds.), Issues in mentoring, (pp 25-34). London: Routledge /Open University, http://www.nickols.us/homers_mentor.htm visited 27-11-2014

Boud, D. and Feletti, G., Eds. (1991). The Challenge of Problem-Based Learning. New York: St. Martin"s Press.

Brophy, S. P. (1995). Computer partner in the classroom: Fostering small group problem solving. Proceedings from the Computer Support for Collaborative Learning 1995 Conference.

Carden, S. J. (2010). Formal mentoring programmes; Management Review, Vol. 13, No.5, pp. 617-623.

Churchill. D. (2003).Effective design principles for activity-based learning: the crucial role of 'learning objects' in Science and engineering education. Retrieved from http://www.learnerstogether.net/PDF/Effective-Design-Principles.pdf on 10 Oct, 2014.

Darwin, A. (2000). A critical reflections on mentoring in work place settings. Adult Education Quarterly, Vol. 51 No.3, pp. 195-199.

Donaldson, S. et. al. (2005). Longitudinal examination of mentoring relationships on citizenship behavior; International Journal of Career and Professional Development, Vol. 26 No. 7, pp. 233-249.

Donaldson, S., et.al.(2003). Longitudinal examination of mentoring relationships on organizational commitment and citizenship behavior. Journal of Career and Professional Development, Vol. 26 No. 6, pp. 239-246.

Edward, N.S. (2001). Evaluation of a constructivist approach to student induction in relati on to students' learning style. European Journal of Engineering Education, Vol. 26(4) 429-440.

Ensher, E. A. et.al.(2004). Comparison of traditional, step-ahead, and peer mentoring on mentees support, satisfaction, and perceptions on career success; A social exchange perspective.Journal of Psychology and Business, Vol.15, No. 1,pp. 411-430.

Ensher, E. et.al.(2006). Online mentoring and computer-mediated. Thousand Oaks, CA: Corwin Press, Inc.

Feiman and Parker (2009).Mentoring in context: a comparison of two U. S. programmes for beginning teachers. East Lansing MI: National Center for Research on Teacher Learning, Michigan State University.

Fitzgeerald, M. G. (1961). Demystifying gender differences in mentoring; theoretical perspectives and challenges for future research on 
gender and mentoring. Human Resources Development Review, Vol.5, pp. 148-175.

Foster, W. \& Clark, M. (2011). Online Advance Leadership. Faculty Mentoring in Higher Education. Thousand Oaks, CA: Corwin Press, Inc Freud, J. \& Jung K. (2010). The odyssey of homer done into English prose. London: Macmillan.

Goodwin, D. (2006). Everyone needs a mentor; The Science Teachers Mentoring. Vol. 63, No.6, pp.55-59.

Hake, R. R. (1998). Interactive-engagement versus traditional methods: a six-thousand-student survey of mechanics test data for introductory physics courses. American Journal of Physics, Vol. 66(1), 64-74.

Hake, R. R. (1998). Interactive-engagement versus traditional methods: a six-thousand-student survey of mechanics test data for introductory physics courses. American Journal of Physics, Vol. 66(1), 64-74.

Harel, I., \& Papert, S. (1991). Software design as a learning environment. Interactive Learning.

Harfield, T., Davies, K., Hede, J., Panko, M.\& Kenley, R. (2007). Activity-based teaching for Unitec New Zealand construction students. Emirates Journal for Engineering Research, 12 (1), 57-63 (2007)

Hein, G. (1991).Constructivist Learning Theory. Retrieved from http://www.exploratorium. edu/IFI /resources / constructivistlearning. html. on 19 Nov,2014.

Huwe, J. M. (2003). Toward a typology of mentorship dysfunction in graduate schools. Psychotherapy; Theory, Research, Practice in Teaching, Vol.39, pp.44-55.

Johnson, M. (2007). Diversified mentoring relationships in organizations; A power perspective. Academy of Management Review, 22(2), 482-521.

Johnson, S. and Gray R. (2010).Independent of methods of research design. A handbook of mixed methods in social and behavioral research. Thousand Oaks, CA: Sage Publications.

Kafai, Y.B., \& Resnick, M. (Eds.). (1996). Constructionism in practice: designing thinking, and learning in a digital world. Mahwah, $\mathrm{NJ}$ : Lawrence Erlbaum.

Kasprisin, et. al. (2003).Testing e-training to improve e- mentoring programmes for diversity in higher; Me Building a Better Bridge. Mentoring \& Tutoring, Vol. 17 No.1, pp. 69-75.

Kram, K. E (1983). Phases of the mentoring relationship; Academy of Management Journal. Mentoring \& Tutoring, Vol. 18 No.1, pp. 60-65.

Kram, K. E. (1983). Phases of the mentoring relationship; San Francisco, CA: Jossey-Bass.

Kram, K. E. (1985). Mentoring at work. Glenview. Scottland: Foresman \& Co.

Lebuffe, 1994; Morey, 1990; Tilgner, (1990)Problem-based learning: what and how do students learn? Educ. Psychol. Rev., 16(3), $235-266$.

Lewis, J. (2004). Cross-cultural connections. Mentoring programs can bridge gaps between disparate groups. San Francisco, CA: Jossey-Bass.

McFarlin, D. B. (2010). Perceptions of mentor roles across the gender mentoring relationships; Journal of Vocational Behavior, Vol. 37, No. 2, pp. 321-339

Miller, L. (2004). Teacher Leadership. San Francisco: Jossey Bass, Inc.

Murphy, S. E. et.al (2006). Gender, ethnicity, development, and risk; Mentoring and the consideration of individual differences. Journal of Psychology and Social Sciences, Vol. 34, No. 6, pp. 765-779.

Murray, P., Donohoe, S., and Goodhew, S. (2004). Flexible learning in construction education: a building pathology case study. Structural Survey, Vol. 22(5) 242-250.

Noe, R. (2008). Women and mentoring; A review and research agenda. Academy of Educational Management, 13(0), pp. 69-75.

Odell, S \& Huling, L. (2010). Implications for Teacher Induction and Mentoring Programmes. Journal of Teacher Education: Research on learning to teach, EBSCO, Publishing.

Odell, S. (1990). Preparing teachers for professional leadership; Action in Teacher Education. Academy of Educational Management, 13 (1), pp. 19-25.

Ragins, B. R. (2009). A study on the effects of sex and gender role into the investigation on mentorship; in male dominated occupations. Journal of Vocational Behavior, Vol.41, No. 1, pp. 250-261.

Ragins, B. R. et.al. (2012). Marginal mentoring; Effects of type of mentor, quality of relationship. Programme design on work and career development. Academy of Management Journal. Vol.5, No. 2,pp. 40-40.

Stolen. M. (2009). Activity-based Learning Experiences in Quantitative Research Methodology for (Time-Constrained) Young Scholars Course Design and Effectiveness. POMS $20^{\text {th }}$ Annual Conference, Orlando, Florida, U.S.A.

Teo, R. \& Wong, A. (2000). Does Problem Based Learning Create A Better Student: A Refelection? Paper presented at the 2nd Asia Pacific Conference on Problem -Based Learning: Education Across Disciplines, December 4-7, 2000, Singapore.

Williams, E. A. \& Scandura, T. A. (2001). An investigation of the moderating effects of gender on the relationships between mentoring initiation and mentees perceptions of mentoring functions. Journal of Vocational Behavior, 59, 342-363.

Williams, T. C. (2008). To create effective mentoring relationships for the teachers; a strategy for the mentor and mentee success. Intervention in Schools and Clinics. Vol. 25, pp. 39-41.

Yoder, K. E. (2001). Re-conceptualizing mentoring at work; A developmental network perspective. The Academy of Management Review, Vol.26, No.1, pp. 260-281.

Zuckerman, H. (2001). What's in a mentoring; A literature-based approach to understanding mentoring, coaching, and other constructs that describe developmental interactions. Human Resource Developmental Review, Vol.10, No. 1,pp. 11-14. 